\title{
I. Report on the travels of C. Olivier and C. Bruguiere, undertaken by order of the French government, through the Ottoman empire, Egypt and Persia, during the years 1792, 93, 94, 95, 96 and 97
}

\section{Olivier}

To cite this article: C. Olivier (1799) I. Report on the travels of C. Olivier and C. Bruguiere, undertaken by order of the French government, through the Ottoman empire, Egypt and Persia, during the years 1792, 93, 94, 95, 96 and 97, Philosophical Magazine Series 1, 3:12, 337-347, DOI: $10.1080 / 14786449908677006$

To link to this article: http://dx.doi.org/10.1080/14786449908677006

册 Published online: 25 Jan 2010.

Submit your article to this journal ¿

Џll Article views: 3

Q

View related articles 
THE

\section{PHILOS OPHICAL MAGAZINE.}

$M A r 1799$.

1. Report on the Travels of C. Olivier and C. BRvGUIERE, undertaken by order of the French Government, tbrougl tbe Ottoman Empire, Egypt and Perfia, during the Years 1792, 93, 94, 95, 96 and 97. Read in the Sitting of the National Infitute, February 14tb. By C. Olivier.

IN $\mathrm{N}$ the year 1792 the provifional executive council, fenfible of the advantages which might refult to commerce, agriculture, natural hiftory, geography, medicine, \&c. by a tour through the Ottoman empire, Egypt and Perfia; perfuaded that thefe interefling countries had never been confidered under a proper point of view, or had been confidered only partially, and that we had ftill much to learn refpecting them, made choice of C. Bruguiere and myfelf to accomplifh that object.

After fome delays, we at length failed from Marfeilles, in April r793, in a neutral veffel, and, without touching any where by the way, arrived at Conftantinople, after a pleafant voyage, on the $2 \mathrm{I}$ it of May.

It would be difficult to exprefs the different fenfations excited in the traveller by the firft view of that large city and

Vol. III,

$z$ its 
its inhabitants. The mixture of trees, houfes and minarets? the canal of the Black Sau, the hills and valleys by which it is bordered, Scutari and the numberlefs villages fituated on its fhores, the fea of Marmora with its iflands, Mount Olympus covered with fnow, the variegated and fertile fields of Afia and Europe, all tugether prefent fo many pictures which at once delight and aftonifl. One cannot help admiring the natural beauty of the environs of Conftantinople, and reflecting at the fame time on the happy fituation of that large city, which can be fo fpecdily fupplied with provifons; which is fo eafy to be defended, and which enjoys the advantage of a port fo fafe, fo commodious, and of fuch an cxtent. But if we caft our eycs a little farther, we behold the two fhores of the entrance into the Black Sea, for the fpace of feteral lcagues, convulfed by fubterranean fires. Different ftrata of lava, decompofed rocks, porphyry and mranites of various colours, more or lefs aitered, atteft the flow and fucceffive action of a great volcano. If we afcend a few leagues, we difcover, for a vaft cxtent, a mine of coal, which the Turks have not yet found means to work.

Ve remeined fix wecks in this capital of the Ottoman cmpirc, wating the exvoy extraordinary of the Republic fnould receire from the miniter orders refpeting our miffion and allowanes; but the attention of government was at that time cngaged with objects of more importance. Our letters remained unaniwered, and we fhould have been thrown into freat embarrafiment had not our prefing wants been fupplied by the envoy of the Renublic.

After viewing this country, fo interefing in every refpect, and making an anple collection of plants, birds, fifhes, infects, fhells and mincrals; and after fending two packages of feeds at different times to the national garden of plants, we fet out for the Dardariefles, by which means we had it in our power either to proceed to the Archipelago in the fpring, or to return to Conftantinople in order to direct our courfe fowarks the fouthern fhores of the Black Sea; to proced through 
through Armenia, Georgia, Ghilan, or Chirvan, to the borders of the Cafpian fea; afterwards to traverfe Perfia from north to fouth, and to return by the Perfian Gulph, Buffora, Bagdad, Mefopotania and Aleppo. As we did not, however, hear from government, and could receive only a. part of our allowance, tre confined ourfelves to excurfions to different places in the miynbourhood of the fea of Marmora, the chanuel of the Dardanelles, rroade, Tenedos, Scio, fome parts of the coalt of Narolia, Mycone and Naxia, from which we proceeded to Crete.

Agreeably to our inftructions, we had tranfmitted in Conflantinople, to be reared in the garden of the ambaffador's palace, plants of a kind of apple-tree with oblong fruit of an excellent flavour, proper to be cultivated in any part of France, but more particularly in the fouthern clepartments; plants of threc kinds of oak not found in our forefts or gardens-one kind proper for thip-building-another à grand cuputs known in commerce by the namc of avellon's, which is the quercus agilops; and lattly, that which furnithes the galls of the Levant: we addcd alfo fereral thrubs deftined to eurich the rational garden of plants.

Though feverial well informcd Lurogeans have traverfed this part of the Ottoman cmpire; though many of them have publifhed interefling obfervations on the political relations of the Turks, their manners, ufages, and religion; and though we have cxcellent works on the plants and ancient hiftory of thefe countries, we, however, found that there $\mathrm{s}$ ftill an abundant harveft to be reaped, even in the beft known part of natural hiftory, that is to fay, in regard to plants. But when we refleet that the reptiles, river fifh, infects and terreftrial thells in thofe diftricts have not been obferved by any traveller; that no one has made us acquainted with the riches which the Turks poffets in mineralogy, mines of iron and copper, pozzolana, and coals at the very gates of the capital, marble of all kinds exceedingly abundant in the iflands of the fea of Marmora and the Archipelago, agates, 
comelians and chalcedonies in the fiffures of the volcanic rocks, mines of atum and fulphur, mineral waters of every kind; in a word, if we recollest that no traveller has confidered this country in regard to geology, that part of natural hiftory fo interefting, which by enabling us to obferve the different ftrata of earth and ftones, the direction and ftructure of mountains, and to compare the different foffils that one meets with, mult neceflarily conduct to a certain knowledge of the antiquity of our globe, of the laws to which it is fubject, and of the different cataftrophes it has experienced, and of which fome faint light has been tranfmitted to us by the fabulous hiftory of antiquity, will be readily perfuaded that our obfervations, directed to thefe objects, cannot fail of being highly interefting.

We remained four months at Candia; and though two years had elapled fince our departure from Paris, we had received no intelligence from governmert: We were, therefore, of opinion, that it would be abfolutely neceffary for us to renounce our firt plans; but as we were defirous of employing our time in the moft ufeful manner poffible, we refolved to proceed to Egypt, and to traverfe that country fo abundant in fubjects of obfervation, and as interefting for the politician and ftatefman, as for the philofopher, naturalif and antiquarian.

The fituation of the French in Egypt was extremely difagreeable: their commerce had been interrupted, and they were in a fate of oppreffion at Cairo. Some of them had been maltreated by the government, and the conful of the Republic enjoyed no confideration. Our firft care was to ftudy the monftrous government of the Mamelouks, their military force and their manners; to make ourfelves acquainted with the revenues of Egypt, the prefent ftate of its commerce, and that which it might be fufceptible of under a juft and enlightened government. We examined the ports of Alexandria, the road of Aboukir, the Delta, the courfe of the Nile, its periodical inundation, the canals which the 
megligence of the Mamelouks has fuffered to be fillcd up, the monuments reared to gratify the pride of kings, and thofe which have been conftructed in confequence of religious duties. We directed our view, at the fame time, to the natural productions of Egypt, and thofe which might be introduced into it by cultivation; the fertility of its foil, and the difeafes to which the inhabitants are expofed. We enquired into the caufe of the periodical winds. In the latt place we examined whether the plague, that malady fo fudden and fo terrible in its effects, has its fource in Egypt, as fome travellers have afferted, or whether it be there only cafual and cpidemic. Our harveft, in regard to natural hiftory, has been very abundant: we had an opportunity of tranfmitting to the national garden of plants a third box of feeds from the Archipelago, Candia and Egypt.

On the 23d of March we received letters from the envoy extraordinary, by which he invited us to quit Egypt and to return to the thores of the Bofphorus; becaufe the time was at length arrived for carrying into effect the plans we had formed. "Regions lying farther to the Eaft," faid he, " now invite you, and I winh to confer with you before you proceed thither."

Under the fame cover there were two letters of C. Desforgues, minifter of foreign affairs. One was a copy of that which the minifter wrote to $C$. Defcorches; in which he requefted from him an eftimate of the fums neceffary to be expended, in order that we might properly difcharge our miffion. He authorifed him to fupply us with whatever fums might be requifite, to procure fuch guides and information as the nature of our miffion required, and to obtain thofe documents which were indifpenfibly neceffary for our refearches and obfervations. He concluded lis letter with the following words: "In all cafes thefe two obfervers of nature will be fubordinate to your commands; they will give you an account of all their operations, and at the end of each month you will tranfmit to me the refult of their 
obfervations on the arts, fciences, natural hiftory, commerce, and political ftate of the countrics through which they pafs, in order that $I$ nay give a faithful reprefentation to the executive council, of their zeal, their labours, and their difco. veries."-In the other, the minifter informed us, that he had requefted $\mathrm{C}$. Defcorches to give him an account of the ordinary expences to which we would be fubjected. He concluded by defiring us to tranfmit our fubmiffion in writing to C. Deficorches, and to conform to the difpofitions contained in the letter which he had addreffed to him.

We embraced the earlieit opportunity of complying, both with the orders of the minifter, and thofe of the envoy. We tranfmitted our fubmifion; and, having terminated our obfervations on Cairo and the neighbourhwod, repaired, without delay, to Alexandria. We failed from that port on the 3 oth of April, and arrived at Conftantinople after a navigation of forty-eight days. We had the pleafure of touching at the inles of Rhodes and Lcro, which we had not before feen. The repairing of a leak in our veffel obliged us to remain eight days at the former; and we were detained as long at the latter on account of the North winds.

During this interval C. Defcorches had been fucceeded by C. Verniac. We thereforc delivered to the latter a fketch of our operations, from the period of our arrival in the Eevant; a ftatement of the fums we had received; and a mimute memoir on the fituation of the French in Egypt, the government of the Mamelouks, the productions and revenue of the country, the cultivation of the land, on its commerce, and laftly on the improvements of which the country was fufceptible . This memoir concluded with reflections ex-

cited

- Tle following extraet finm Norden's Travels, refpeding a tradition in Egypr, that the country would be vifited by fpies, who would report its fate. and at latt ling a great nuiplec of Franks who would conquer it may amufe fome of our readers, and by fome will be thought perhaps not inapplicable to C. Olivier's mifinon, and the crents that have followed it: 
cited by the order which $C$. Defcorches had given to the conful and French at Cairo, to repair provifionally to Alexandria, and put themfelves under the protection of the port captain of the Grand Signior; and to wait there until more favourable circumftances flould enable the conful to refume his functions at Cairo, and the merchants their commercial operations. We forwarded to the national garden of plants a fourth box of the feeds from Egypt, Rbodes, Lero, and the fhores of the channel of the Darcianelles, as well as a live ichneumon which we had reared for four or five months.

Perfia, a prey to the horrors of civil war fince the reigns of the latter Sophis (the family of the Sephevi), gave reafon to hope for a flourifting kingdom under a monarch who had triumphed over all his rivals, and had deftroyed each of them in fucceftion. The opportunity was then favourable

"January 4, 773 3.-On this day (Saturlay) the Danifh traveller, Captain Norden, with his attendants, arrived at Deir, or Derr1, the firft large village or town in Nubia. The cacheff of that place, a notorious plunderer of all who fell in his power, conducted himfelf towards the travellers in fo infamous a manner, as to oblige the captain to rclinquith his defign of proiceding further, and return to Cairo. When difputing about fome of the exorbitant demands of the cachefif, one of the company reminded him that they were under the protection of the Grand Signior. To which he anfwered in a paffion; 'I laugh at the horns of the Grand Signior: I am here Grand Signigr myfelf, and I will teach you to refpect me as you ought. I know already what fort of people you are. I have con. fulted my cup; and I have found by it, that you are thofe of whom one of our prophets has faid: That there would cone Franks in difguife, who, by little prefents, and by foothing and infmuating behaviour, would pafs cvery where, examine the ftate of the country, go afterwards to make a report of it, and bring at laft a great number of othcr Franks, who would conciuer the country, and extcrminate all. But I will take care about that; and without further delay you muft quir my k,ark.' After being plundered by him, in varivus ways, till the evening of the following Monday, the travellers thought theinfelves very fortunate in being permitted to efcape with their lives.- [Dr. Timpleman's Tranfation of Norden's Travels, 8 vo. clit. 1757, vol. ii.p. I50.] EvIT. 
for travelling into the interior parts of this country, fo interefting in every point of view. C. Verniac allowed us the whole of our appointment, authorifed us to engage a dragoman, gave us a letter to the chief minifter of the king of Perfia, another to the pacha of Bagdad, and, at the fame time, various inftructions both verbally and in writing.

At the moment of our departure, the Porte had a defign of conftructing in the harbour of Conftantinople a bafon after the model of that of Toulon; and fome Armenian merchants wifhed to prevail on us to communicate to them a difcovery we had made of an excellent kind of pozzolana, by offering us the fum of 30,000 piaftres. As we were here under the orders of the Republic, we did not think ourfelves at liberty to enter into any treaty with Armenians, in regard to our difcoveries, until we had apprifed the cnvoy of the Republic. C. Verniac, who intended to get this bafon confructed by French engineers, defired us to reject the offers of the Armenians, promifing to procure us a more ample recompence from the Porte; and he immediately fent the firnt dragoman of the legation to the Turkifh government, to communicate our difcovery, and make an offer of our fervices. The Porte feemed to accept this offer with gratitude; and having requefted a note on the fubject, we embraced the earlieft opportunity of tranfmitting to it a memoir, in which we faid that we had difcovered pozzolana of an inferior quality near the channel of the Black Sea, in Prince's iflands, and various iflands of the Archipelago; and fome of a fuperior quality, or at leaft equal to that of Italy, in the illand of Santorin. The memoir concluded with a few details refpecting the method of cmploying both.

The nimifters of the l'orte, when they received this memoir, informed the dragoman, that the Armenians had demanded for the difcovery 60,000 piaftres, though they had offered us only 30,000 . They added, that they would never forget the fervice which we rendered to them, and that their gratitude would be boundlefs if we could effect what we promifed. 
promifed. On this fubject we had two interviews with the Chelebi-Effendi; and that minifter twice gave us reafon to hope that the Porte would reward, in a manner worthy of itfelf, the important difcovery we had communicated.

In the mean time we were juft on the point of proceeding on our journey to Perfia. The necefary preparations were already made, and we were looking out for a caravan going to Diarbekir, when the Porte required that we thould repair to the illes of Santorin, Milo, and Argentiera, and tranfmit to it fome bags of pozzolana, in order that previous experiments might be made. For this purpofe it freighted a French veffel, and fent a chiaous to accompany us and bring back the fpecimens. We wcre obliged to touch at Metelin to receive from the captain pacha, then lying at anchor before that inland, the neceffary firmans.

The inhabitants of Santorin, alarmed at this difcovery, and fearing that the Ottoman government would caufe the earth to be dug up at their expence, and of courfe fend Turkith officers into the ifland, immediately affembled to execute the Grand Signior's orders, and to devife means for warding off the blow with which they were threatened. 'They thought they could do nothing be ter than to fend the primates to the Latin bifhop at whofe houfe we lodged, and to offer us a prefent if we would inform the Porte that we had difcovered none of the above fubftance in the inland. We, however, rejected the offer of thefe primates, and tranfmitted to Conftantinople feveral bags filled with pozzolana of an excellent quality, which was in great abundance, and exceedingly eafy to be dug up. We depended on C. Verniac for the promifed recompence to which we thought ourfelves entitled by the importance of the difcovery, by rejecting the offers of the Armenians, and the trouble, dangers, and delay we had experienced.

The inland of Metelin, almoft entirely volcanic, is remarkable on account of its great fertility, its immenfe ports, and its warm mineral fprings. Argentiera, known formerly 
under the name of Cimolus, is entirely volcanic. We rew marked, with pleafure, that the Cimolcan carth, which it furnithes in abundance, is produced by a flow and gradual decompofition of the poiphyries occafioned by fubterranean fires. I colleeted fpecimens of that earth in all the ftates through which it pafes. This obfervation will be interefting, no doubt, to mineralogifts, and make them acquainted with the origin of a fubfance hitherto little known. The illand of Milo is altogether voleanic. It prefents a vaft port, on the borders of which is a fpring of warm aluminous water; a very warm grotto, where feather alum is formed; a volcano fill burning, and a prodigious quantity of catacombs. The inand of Santorin is remarkable for the changes effected in it by a volcano, and the finking down of a great part of the ifland; from which has refulted a kind of port, more than two leagues in extent, and from the bottom of which three inles have been thrown up at different known periods. The rupture occafioned by the almolt circular finking down of the inland exhibits different ftrata of volcanic fubftances, among which we obferved feveral kinds of pozzolana. That which we fent to Conftantinople, and of which I have fpecimens, may one day ferve for fuch maritime conftructions as the French may think proper to make in Egypt, when they are once firmly eftablifhed in that country.

We touched a fecond time at Rhodes, proceeded thence to Baruth, and afterwards to Sayd, with a view of going to Damafcus to take advantage of the departure of a caravan for Bagdad, as we had been taught to expect; but, the caravan having departed a long time before, we were obliged to return and take the route to Aleppo. We were unwilling to quit the coaft of Syria without paying at Tyre a tribute of admiration to which that city was fo juftly entitled.

As the road from Latakia to Aleppo is never fafe, we waited fome days for the departure of a caravan. During that time we tranfinitted to the national garden of plants 


$$
\text { Procefs of making Attar, } \mathscr{G}_{0} \text {. }
$$

a fifth box of feeds, from the inlands we had vifited, and the coafts of Syria, On our arrival at Aleppo we employed our. felves in examining the fituation of the French in that city. We collected information refpecting the commerce carried on by the Europeans with the inhabitants, and fent to C. Verniac a memoir on that fubject. We alfo made various obfervations in regard to natural hiftory and geology. We procured feceral birds, and a few quadrupeds : after which we fet out, towards the end of winter, in company with a caravan; and, paffing through Orfa, Merdin, Nebin, and Moful, arrived at Bagdad without any accident.

(To be concluded in the next Number.)

II. Procejs of making Attar, or Effintial Oil of Rofes. By Lieut. Col. Polier. From the Afiatic Refearchics.

T

$\mathrm{HE}$ attar is obtained from the rofes by fimple diftillation, and the following is the mode in which $I$ have made it.

A quantity of frefh rofes, for example forty pounds, are put in a fill with fixty pounds of water, the rofes being left as they are with their calyxes, but with the ftemis cut clofe. The mafs is then well mixed together with the hands, and a gentle fire is made under the fill: when the water begins to grow hot, and fumes to rife, the cap of the fill is put on, and the pipe fixed; the chinks are then well luted with parte, and cold water put on the refrigeratory at top: the receiver is alfo adapted at the end of the pipe; and the fire is continued under the ftill, neither too violent, nor too weak. When the impregnated water begins to cone orer, and the fill is.very hot, the fire is leffened by gentle degrees, and the diftillation continued till thirty pounds of water are come over, which is generally done in about four or five hours: this rofe-water is to be poured again on a frefh quantity (forty pounds) of rofes, and from fifteen to twenty pounds of 